\title{
TUMBUHAN LOKAL SEBAGAI BAHAN BAKU PRODUK MINUMAN HERBAL FUNGSIONAL DI KABUPATEN JEMBER
}

\section{LOCAL PLANT AS RAW MATERIAL OF FUNCTIONAL HERBAL DRINK AT JEMBER REGENCY}

\author{
Veni Anggraini ${ }^{1)}$, Novy Eurika ${ }^{2)}$, Sawitri Komarayanti ${ }^{3)}$ \\ Program Studi Pendidikan Biologi, FKIP, Universitas Muhammadiyah Jember \\ Email: veni.hanni@yahoo.com
}

\begin{abstract}
ABSTRAK
Kabupaten Jember merupakan salah satu wilayah komoditi tumbuhan herbal lokal. Penelitian ini bertujuan untuk mengidentifikasi jenis tumbuhan lokal yang digunakan sebagai bahan baku pembuatan minuman herbal fungsional di Kabupaten Jember. Jenis penelitian ini adalah deskriptif kualitatif, dilakukan pada bulan April-Mei 2018. Lokasi pengambilan sampel yaitu Kabupaten Jember dengan teknik purposive sampling dan snowball sampling. Teknik pengumpulan data dilakukan dengan wawancara, observasi dan studi dokumen. Hasil penelitian identifikasi menunjukkan jumlah keseluruhan tumbuhan herbal lokal yang dimanfaatkan sebagai bahan baku minuman herbal fungsional adalah 27 jenis tumbuhan. Minuman herbal dibuat dengan memanfaatkan salah satu organ tumbuhan seperti; daun, rimpang, buah, akar dan biji.Organ tumbuhan yang banyak dimanfaatkan adalah daun.
\end{abstract}

Kata Kunci: Tumbuhan Lokal, Bahan Baku, dan Minuman Herbal Fungsional

\begin{abstract}
Jember Regency is one of the local herbs commodity area. This study aims to identify the types of local plants that are used as raw material for making functional herbal drinks in Jember Regency. This type of research is qualitative descriptive, conducted in April-May 2018. The sampling locations were Jember Regency with purposive sampling and snowball sampling techniques. Data collection techniques are carried out by interviewing, observing and studying documents. The results of the identification study showed that the total number of local herbal plants used as raw materials for functional herbal drinks were 27 plant species. Herbal drinks are made by using one of the plant organs such as; leaves, rhizomes, fruit, roots and seeds. Plant organs that are widely used are leaves.
\end{abstract}

Key words: Local Plants, Raw Material, and Functional Herbal Drinks 


\section{PENDAHULUAN}

Kondisi tanah yang subur, iklim yang baik serta didukung oleh keanekaragaman flora menjadikan Indonesia sebagai negara penghasil komoditas herbal yang cukup potensial (Mabel dkk., 2016). Kabupaten Jember merupakan salah satu wilayah Indonesia yang memiliki komoditi tumbuhan herbal.Berdasarkan hasil survei, terdapat delapan industri minuman herbal fungsional yang tersebar di beberapa kecamatan yang meliputi Kecamatan Sumbersari, Kecamatan Tempurejo, Kecamatan Kaliwates, Kecamatan Wuluhan, Kecamatan Tanggul dan Kecamatan Ledokombo. Ketersediaan tumbuhan herbal dari masing-masing wilayah industri, menjadikan beberapa organ tumbuhan herbal sebagai bahan utama pembuatan minuman herbal fungsional.

Berdasarkan data dinas tanaman pangan dan hortikultura Kabupaten Jember (2016), terdapat 15 jenis tumbuhan herbal yang dibudidayakan oleh masyarakat, diantaranya jahe, laos/lengkuas, kencur, kunyit, lempuyang, temulawak, temu ireng, temu kunci, dringo, kapulaga, mengkudu, mahkota dewa, kejibeling, sambiloto dan lidah buaya. Beberapa jenis tumbuhan herbal telah diketahui manfaatnya bagi kesehatan melalui pengetahuan masyarakat dalam mengolah tumbuhan tersebut menjadi minuman herbal fungsional yang berkhasiat bagi kesehatan (Rifkowaty dkk., 2016). Terdapat beberapa industri minuman herbal fungsional di wilayah Kabupaten Jember, sebagian besar minuman herbal yang diproduksi memanfaatkan bagian tumbuhan herbal sebagai bahan baku pembuatan minuman.Tumbuhan herbal digunakan sebagai bahan baku pembuatan minuman herbal fungsional oleh masyarakat, namun hanya beberapa jenis saja yang umum dimanfaatkan, hal ini disebabkan terbatasnya pengetahuan masyarakat akan jenis-jenis tumbuhan herbal yang dapat dimanfaatkan sebagai bahan baku pembuatan minuman herbal fungsional. Bahan baku merupakan bahan utama dalam proses pembuatan minuman herbal, bahan baku ini dapat berasal dari organ tumbuhan seperti buah, bunga, daun dan rimpang (Hakim, 2015).

Minuman herbal dapat dijadikan sebagai suatu produk olahan industri rumah tangga yang terbuat dari bagian-bagian tumbuhan yang memiliki khasiat bagi kesehatan dan dikonsumsi dengan cara diseduh dengan air mendidih (Tasia \& Widyaningsih, 2014).Tujuan yang ingin dicapai pada penelitian ini adalah untuk mengidentifikasi jenis 
tumbuhan lokal Kabupaten Jember yang dapat digunakan sebagai bahan baku minuman herbal fungsional.

\section{METODE PENELITIAN}

Penelitian ini merupakan jenis penelitian kualitatif.Penelitian dilakukan pada bulan April-Mei 2018.Informan dalam penelitian merupakan pelaku industri minuman herbal fungsional di Kabupaten Jember.Penentuan informan dilakukan dengan cara metode purposive sampling dan metode snowball sampling. Data penelitian berupa data primer dan data sekunder. Data primer merupakan data yang diperoleh peneliti secara langsung melalui wawancara dan observasi, sedangkan data sekunder adalah data yang diperoleh peneliti tidak secara langsung namun menjadi data penunjang dalam penelitian, semisal melalui orang lain dan dokumen-dokumen terkait (Sugiyono, 2015).

Data primer dalam penelitian adalah jenis-jenis tumbuhan herbal yang digunakan sebagai bahan baku pembuatan minuman herbal fungsional, meliputi nama lokal dan bagian tumbuhan yang dimanfaatkan. Data primer dikumpulkan dengan cara observasi jenis-jenis tumbuhan herbal yang tumbuh dan berkembang pada lahan tanam di wilayah Kabupaten Jember. Data sekunder berupa data yang diperoleh dari Dinas Perindustrian dan Perdagangan Kabupaten Jember terkait industri minuman herbal dan data tumbuhan herbal lokal dari Dinas Tanaman Pangan, Hortikultura dan Perkebunan Kabupaten Jember.Teknik pengumpulan data yang digunakan adalah wawancara, observasi dan studi dokumen.Alat dan bahan yang digunakan selama proses pengumpulan data yakni pedoman wawancara, alat tulis, perekam suara, penggaris, catatan lapang, kamera, dan google map.

Sampel tumbuhan yang diperoleh didokumentasi dan diidentifikasi.Identifikasi tumbuhan didasarkan pada ciri morfologi tumbuhan yang ditemukan meliputi ciri morfologi daun, batang, akar, buah, bunga dengan mengacu pada beberapa buku-buku taksonomi seperti buku Flora untuk sekolah di Indonesia (Tjietrosoepomo, G, 2000) dan buku Taksonomi Umum/ Taksonomi Tumbuhan Obat-obatan (Tjietrosoepomo, G. 2016). Data tumbuhan herbal lokal Kabupaten Jember ditabulasi dan disajikan dalam bentuk tabel dan dianalisis untuk mengetahui jenis-jenis tumbuhan herbal lokal yang 
digunakan sebagai bahan baku pembuatan minuman herbal fungsional di Kabupaten Jember.

\section{HASIL DAN PEMBAHASAN}

Berdasarkan hasil penelitian yang dilakukan di Kabupaten Jember melalui observasi jenis-jenis tumbuhan lokal yang digunakan sebagai bahan baku pembuatan minuman herbal fungsional kepada pelaku industri, ditemukan berbagai jenis tumbuhan herbal yang beragam. Jumlah tumbuhan herbal lokal yang dimanfaatkan pelaku industri minuman herbal yaitu 27 jenis. Berbagai jenis tumbuhan herbal dapat dilihat pada Tabel 1.

Tabel 1.Jenis Tumbuhan Herbal Lokal yang Digunakan sebagai Bahan Baku Minuman Herbal

\begin{tabular}{|c|c|c|c|}
\hline Nama lokal & Nama latin & Famili & $\begin{array}{c}\text { Bagian } \\
\text { yang } \\
\text { digunakan }\end{array}$ \\
\hline 1. Sirsak & Annona muricata $L$. & Annonaceae & Daun \\
\hline 2. Pegagan & Centella asiatica & Apiaceae & Daun \\
\hline 3. Pecut kuda & $\begin{array}{l}\text { Stachytarpheta } \\
\text { jamaicensis } L .\end{array}$ & Verbenaceae & Daun \\
\hline 4. Kumis kucing & Orthosipon spicatus & Lamiaceae & Daun \\
\hline 5. Kelor & Moringa oleifera & Moringaceae & Daun \\
\hline 6. Kemekes & Piper cubeba $L$. & Piperaceae & Daun \\
\hline 7. Sambung nyawa & Gynura procumbens $L$. & Asteraceae & Daun \\
\hline 8. Gempur batu & Borreria hispida Schum & Rubiaceae & Daun \\
\hline 9. Daun dewa & Gynura segetum L. & Asteraceae & Daun \\
\hline 10. Binahong & Anredera cordifilia & Basellaceae & Daun \\
\hline 11. Lidah buaya & Aloe ferox Mill. & Liliaceae & Daun \\
\hline 12. Meniran & Phyllanthus urinaria & Euphorbiaceae & Daun \\
\hline 13. Daun ungu & Graptophyllum pictum & Acanthaceae & Daun \\
\hline 14. Daun sendok & Plantago major $L$. & Plantaginaceae & Daun \\
\hline 15. Katu & Sauropus androgynus $L$. & Euphorbiaceae & Daun \\
\hline 16. Sereh & $\begin{array}{l}\text { Cymbopogan nardus L. } \\
\text { Rendle }\end{array}$ & Poaceae & Daun \\
\hline
\end{tabular}




\begin{tabular}{|c|c|c|c|}
\hline 17. Sambiloto & Andrographis paniculata & Acanthaceae & Daun \\
\hline 18. Murbei & Morus alba $L$. & Muraceae & Daun \\
\hline 19. Mengkudu & Morinda citrifolia L. & Rubiaceae & Buah \\
\hline 20. Som jawa & $\begin{array}{l}\text { Talinum paniculatum } \\
\text { Jack.. }\end{array}$ & Portulacaceae & Akar \\
\hline 21. Kopi & Coffea Arabica & Rubiaceae & Biji \\
\hline $\begin{array}{l}\text { 22. Jahe } \\
\text { a. Varietas jahe } \\
\text { gajah }\end{array}$ & Zingiber officinale Rosc. & Zingiberaceae & Rimpang \\
\hline $\begin{array}{l}\text { b. Varietas jahe } \\
\text { merah }\end{array}$ & $\begin{array}{l}\text { Zingiber officinale Rosc. } \\
\text { Var.Rubrum. }\end{array}$ & Zingiberaceae & Rimpang \\
\hline 23. Kunyit & Curcuma domestica & Zingiberaceae & Rimpang \\
\hline 24. Temulawak & Curcuma xanthorrhiza & Zingiberaceae & Rimpang \\
\hline 25. Kencur & Kaempferia galanga $L$. & Zingiberaceae & Rimpang \\
\hline 26. Kayu manis & $\begin{array}{l}\text { Cinnamomum } \\
\text { zeylanicum }\end{array}$ & Lauraceae & Kulit kayu \\
\hline 27. Delima & Punica granatum $L$ & Punicaceae & Buah \\
\hline
\end{tabular}

Jenis tumbuhan herbal yang ditemukan termasuk dalam divisi spermatophyta, Spermatophyta merupakan kelompok tumbuhan yang memiliki biji yang berfungsi sebagai alat reproduksi generatif (seksual), tubuh dapat dibedakan bagian akar, batang, dan daunnya.Spermatophyta terdiri atas dua sub divisi, yakni sub divisi gymnospermae dan sub divisi angiospermae.Berdasarkan hasil survei data Dinas Tanaman Pangan dan Hortikultura Kabupaten Jember jumlah tumbuhan herbal Kabupaten Jember yang terdata sebanyak 15 jenis tumbuhan, tumbuhan ini tersebar di 24 kecamatan, yaitu Kencong, Puger, Wuluhan, Ambulu, Silo, Mayang, Jenggawah, Ajung, Rambipuji, Balung, Semboro, Jombang, Sumberbaru, Bangsalsari, Sukowono, Sumbersari, Tanggul, Gumukmas, Ledokombo, Jelbuk, Kaliwates, Patrang, Tempurejo, dan Mumbulsari. Dari 27 jenis tumbuhan herbal yang dimanfaatkan sebagai bahan baku minuman herbal, terdapat 7 tumbuhan herbal yang terdata Dinas Tanaman Pangan dan Hortikultura dan telah dimanfaatkan oleh pelaku industri sebagai bahan baku pembuatan minuman herbal, tumbuhan herbal tersebut diantaranya jahe merah 
(Zingiber officinale Rosc. Var. Rubrum), jahe gajah (Zingiber officinale Rosc.), kunyit (Curcuma domestica), kencur (Kaempferia galanga L.), temulawak (Curcuma xanthorrhiza), sambiloto (Andrographis paniculata), mengkudu (Morinda citrifolia L.) dan lidah buaya (Aloe ferox Mill.).

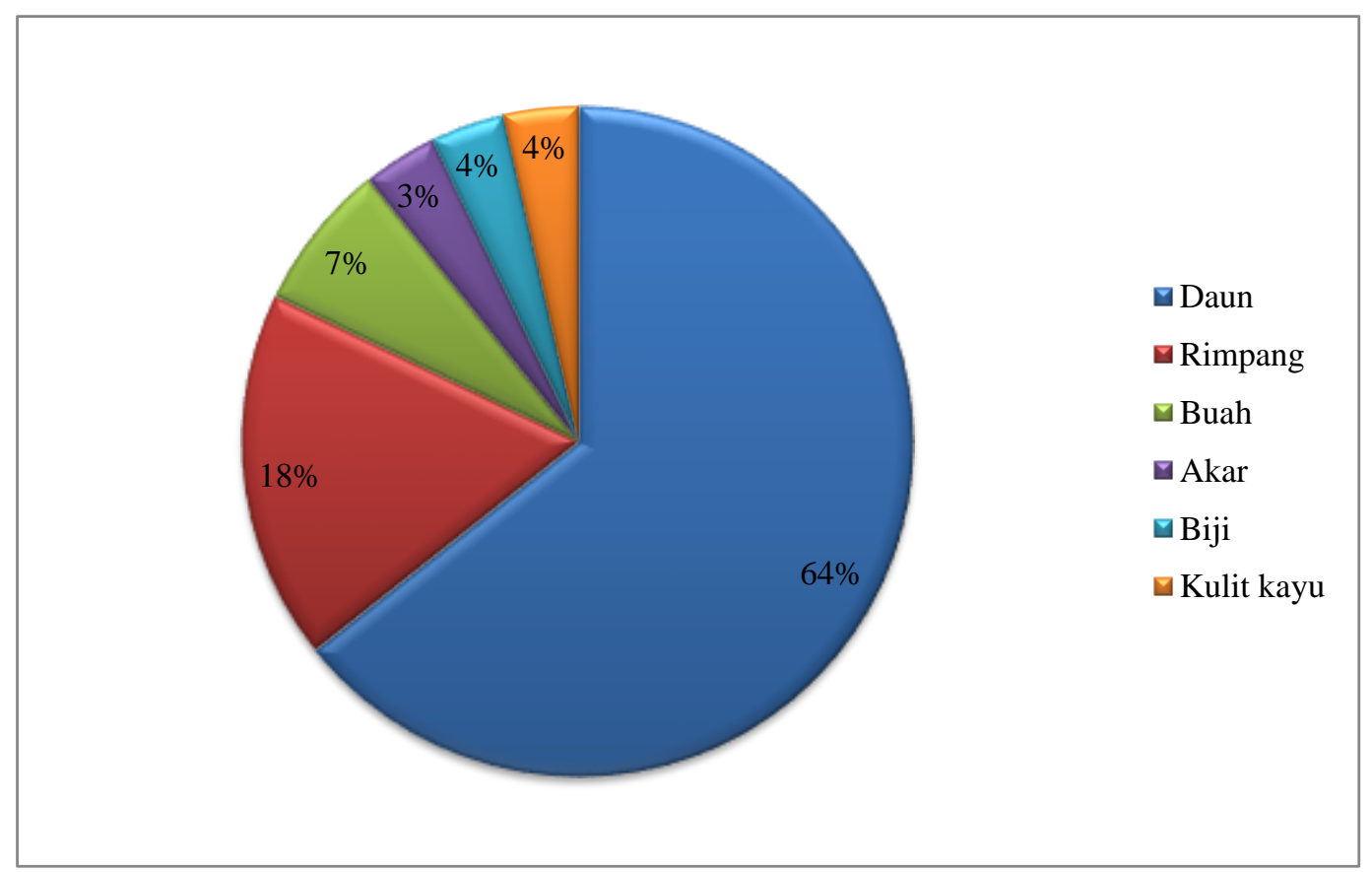

Gambar 1. Presentase Bagian Tumbuhan yang Dimanfaatkan sebagai Bahan Baku Minuman Herbal Fungsional

Berdasarkan gambar 1, dapat diketahui bahwa organ tumbuhan yang digunakan sebagai bahan baku adalah daun, rimpang, buah, akar, biji dan kulit kayu. Terdapat 18 jenis tumbuhan herbal yang dimanfaatkan bagian daunnya, meliputi: sirsak, pegagan, pecut kuda, kumis kucing, kelor, kemekes, sambung nyawa, gempur batu, daun dewa, binahong, lidah buaya, meniran, daun ungu, daun sendok, katu, sereh, sambiloto, dan murbei. Bagian tumbuhan kedua yang paling banyak digunakan ialah bagian rimpang dengan presentase $18 \%$, terdapat 4 jenis, yaitu jahe, kunyit, temulawak dan kencur. Bagian buah yang digunakan sebanyak 2 jenis tumbuhan herbal yaitu delima dan mengkudu dengan presentase $7 \%$ dari seluruh jenis tumbuhan herbal yang dimanfaatkan, dan untuk bagian akar, biji dan kulit kayu masing-masing hanya dari 1 jenis tumbuhan herbal saja yaitu som jawa, kopi dan kayu manis dengan presentase $4 \%$ pada masing-masing tumbuhan herbal. 
Organ tumbuhan yang banyak dimanfaatkan sebagai bahan baku pembuatan minuman herbal fungsional adalah daun. Menurut Yansip (2017), daun banyak digunakan sebagai bahan herbal karena masyarakat percaya bahwa senyawa kimia pada tumbuhan paling banyak terkandung pada daun dibandingkan pada organ lainnya. Mabel (2016) menyatakan daun merupakan bagian yang sangat mudah dijumpai dan selalu tersedia, pengambilan dan pemanfaatannya tergolong mudah dan sederhana, selain itu karena khasiat daun diketahui secara turun temurun lebih banyak dalam segi penyembuhannya dibandingkan dengan bagian yang lain.

Berdasarkan pemaparan pelaku industri, setiap minuman herbal memiliki khasiat berdasarkan bagian tumbuhan yang digunakan. Murtie (dalam Mais dkk., 2018) menyatakan dalam organ daun diduga banyak terakumulasi senyawa metabolit sekunder yang berguna sebagai obat guna melindungi tubuh dari radikal bebas, seperti tannin, alkaloid, minyak atsiri dan senyawa organik lainnya yang tersimpan di vakuola ataupun pada jaringan tambahan pada daun seperti trikoma. Kandungan dan khasiat tumbuhan herbal dapat dilihat pada Tabel 2.

Tabel 2. Kandungan dan khasiat tumbuhan herbal

\begin{tabular}{|c|c|c|c|c|}
\hline No. & $\begin{array}{c}\text { Nama } \\
\text { Tumbuhan }\end{array}$ & Jenis Senyawa & Efek Terapik & Referensi \\
\hline 1. & Sirsak & $\begin{array}{l}\text { Tannin, fitosterol, } \\
\text { hidrat arang, kalsium, } \\
\text { fosfor, zat besi, vitamin } \\
\text { A, B dan C, flavonoid, } \\
\text { dan beberapa } \\
\text { kandungan kimia lain }\end{array}$ & $\begin{array}{l}\text { Sakit pinggul, kejang, } \\
\text { asma, batuk, diabetes, } \\
\text { disentri, demam, } \\
\text { gangguan empedu, flu, } \\
\text { hipertensi, gangguan } \\
\text { pencernaan, cacingan, } \\
\text { malaria, reumatik dan } \\
\text { alternatif pengobatan } \\
\text { kanker }\end{array}$ & Herbie, 2015 \\
\hline 2. & Pegagan & $\begin{array}{l}\text { asiatikosida, } \\
\text { tankunisida, } \\
\text { isotankunisida, } \\
\text { madekasosida, } \\
\text { brahmosida, } \\
\text { brahminosida, asam } \\
\text { brahmik, asam } \\
\text { madasiatik, meso- } \\
\text { inositol, sentelosida, }\end{array}$ & $\begin{array}{l}\text { obat luka, sakit perut, } \\
\text { wasir, keputihan, sifilis, } \\
\text { asma, penyakit ginjal }\end{array}$ & $\begin{array}{l}\text { Tjietrosoepo } \\
\text { mo, } 2016\end{array}$ \\
\hline
\end{tabular}




\begin{tabular}{|c|c|c|c|c|}
\hline & & $\begin{array}{l}\text { karotenoid, } \\
\text { hidrokotilin, vellarin, } \\
\text { tanin serta garam } \\
\text { mineral seperti kalium, } \\
\text { natrium, magnesium, } \\
\text { kalsium, zat pahit } \\
\text { vellarine, triterpenoid } \\
\text { saponin, triterpenoid } \\
\text { genin, minyak esensial, } \\
\text { flavonoid, fitosterol, } \\
\text { dan zat samak }\end{array}$ & & \\
\hline 3. & Pecut kuda & $\begin{array}{l}\text { Saponin, tanin dan } \\
\text { flavonoid }\end{array}$ & $\begin{array}{l}\text { Infeksi saluran kencing, } \\
\text { diuretik, rheumatik, } \\
\text { sakit tenggorokan } \\
\text { (faringitis), pembersih } \\
\text { darah, keputihan, dan } \\
\text { hepatitis A }\end{array}$ & $\begin{array}{l}\text { Sutjiatmo } \\
\text { dkk, } 2015\end{array}$ \\
\hline 4. & $\begin{array}{l}\text { Kumis } \\
\text { kucing }\end{array}$ & $\begin{array}{l}\text { Zat samak, minyak } \\
\text { atsiri, saponin, } \\
\text { sapofonin }\end{array}$ & $\begin{array}{l}\text { Mengobati bengkak dan } \\
\text { infeksi saluran kencing, } \\
\text { diabetes mellitus, batu } \\
\text { ginjal, batuk, dan } \\
\text { radang }\end{array}$ & Kartika, 2017 \\
\hline & Kelor & $\begin{array}{l}90 \text { nutrisi, } 46 \text { jenis } \\
\text { antioksidan, } 36 \\
\text { senyawa antiinflamasi } \\
\text { yang terbentuk secara } \\
\text { alami, serat, beta } \\
\text { karoten } 4 \text { kali lebih } \\
\text { besar dari wortel, } \\
\text { minyak omega-3 dan } \\
\text { klorofil }\end{array}$ & $\begin{array}{l}\text { mempercepat proses } \\
\text { penyembuhan luka, } \\
\text { meningkatkan } \\
\text { kekebalan tubuh untuk } \\
\text { melawan kanker dan } \\
\text { memperlambat } \\
\text { pertumbuhan tumor, } \\
\text { berperan dalam } \\
\text { pembentukan protein } \\
\text { otot, dan metionin yang } \\
\text { berperan menyerap } \\
\text { lemak dan kolesterol }\end{array}$ & Rusita, 2017 \\
\hline & Kemukus & $\begin{array}{l}\text { Alkaloida piperin, } \\
\text { polifenol, kubebin, } \\
\text { epikubebin dan } \\
\text { dihydrokubebin }\end{array}$ & $\begin{array}{l}\text { antiseptik, diuretik, } \\
\text { karminatif, dan } \\
\text { ekspektoran. Khasiat } \\
\text { kemukus terutama } \\
\text { untuk penyakit kelamin } \\
\text { (gonorhea), bronkhitis, } \\
\text { radang kantung kemih, } \\
\text { disentri dan penyakit } \\
\text { perut lainnya }\end{array}$ & $\begin{array}{l}\text { Tjietrosoepo } \\
\text { mo, } 2016\end{array}$ \\
\hline 1. & $\begin{array}{l}\text { Sambung } \\
\text { nyawa }\end{array}$ & $\begin{array}{l}\text { Saponin dan flavanoid } \\
\text { (berupa asam }\end{array}$ & $\begin{array}{l}\text { Diabetes mellitus } \\
\text { karena memiliki sifat }\end{array}$ & $\begin{array}{l}\text { Soetarno } \\
\text { dkk, } 2000\end{array}$ \\
\hline
\end{tabular}




\begin{tabular}{|c|c|c|c|c|}
\hline & & $\begin{array}{l}\text { klorogenat, asam } \\
\text { kafeat, asam p- } \\
\text { kumarat, asam p- } \\
\text { dihidroksi benzoat dan } \\
\text { asam vanilat) }\end{array}$ & $\begin{array}{l}\text { antikolesterol, } \\
\text { antipiretik (penurun } \\
\text { demam), hipotensif } \\
\text { (menurunkan tekanan } \\
\text { darah tinggi), } \\
\text { hipoglikemik } \\
\text { (menurunkan kadar } \\
\text { gula) dan antiinflamasi }\end{array}$ & \\
\hline 8. & $\begin{array}{l}\text { Gempur } \\
\text { batu }\end{array}$ & $\begin{array}{l}\text { Flavonoid, saponin dan } \\
\text { polifenol }\end{array}$ & $\begin{array}{l}\text { antioksidan alami, } \\
\text { antimikroba, serta } \\
\text { membantu metabolisme } \\
\text { protein dan ekspresi gen } \\
\text { PPAR alfa pada } \\
\text { penderita diabetes, } \\
\text { mengobati batu } \\
\text { empedu, obat luar untuk } \\
\text { diare }\end{array}$ & $\begin{array}{l}\text { Sutanto, } \\
2010\end{array}$ \\
\hline 9. & Daun dewa & $\begin{array}{l}\text { Minyak atsiri, senyawa } \\
\text { alkaloid, flavonoid } \\
\text { (berupa asam } \\
\text { klorogenat, asam } \\
\text { kafeat, asam p- } \\
\text { kumarat, asam p- } \\
\text { hidroksi benzoat, dan } \\
\text { asam valinat) dan } \\
\text { saponin }\end{array}$ & $\begin{array}{l}\text { Mengobati luka, } \\
\text { melancarkan sirkulasi, } \\
\text { menghentikan } \\
\text { pendarahan, dan } \\
\text { mengobati infeksi } \\
\text { kerongkongan }\end{array}$ & Rusita, 2017 \\
\hline 10. & Binahong & $\begin{array}{l}\text { Antioksidan, asam } \\
\text { askorbat, senyawa } \\
\text { polifenol, alkaloid dan } \\
\text { flavonoid }\end{array}$ & $\begin{array}{l}\text { Ambeien, batuk, borok, } \\
\text { anemia, disentri, gatal- } \\
\text { gatal, gusi berdarah, } \\
\text { mimisan, jerawat, } \\
\text { kencing manis, } \\
\text { impotensi, penyakit } \\
\text { paru-paru, radang } \\
\text { ginjal, sesak napas dan } \\
\text { usus bengkak }\end{array}$ & Herbie, 2015 \\
\hline 11. & Lidah buaya & Saponin & $\begin{array}{l}\text { Antiseptik } \\
\text { danantibiotik, } \\
\text { penghilang nyeri dan } \\
\text { merangsang } \\
\text { pembentukan sel baru } \\
\text { pada kulit }\end{array}$ & $\begin{array}{l}\text { Nurrani, } \\
2015\end{array}$ \\
\hline & Meniran & $\begin{array}{l}\text { Filantina, hipofilantina, } \\
\text { kalium, damar dan } \\
\text { tannin }\end{array}$ & $\begin{array}{l}\text { Radang ginjal, disentri, } \\
\text { gangguan saluran urine, } \\
\text { hepatitis, demam, } \\
\text { mencret, dan rematik }\end{array}$ & Herbie, 2015 \\
\hline
\end{tabular}




\begin{tabular}{|c|c|c|c|c|}
\hline 13. & Daun ungu & $\begin{array}{l}\text { alkaloid non-toksik, } \\
\text { flavonoid, glikosid, } \\
\text { steroid, saponin, } \\
\text { tannin, kalsium } \\
\text { oksalat, asam format } \\
\text { dan lemak }\end{array}$ & $\begin{array}{l}\text { Sembelit, wasir dan } \\
\text { haid tidak lancar }\end{array}$ & Herbie, 2015 \\
\hline 14. & $\begin{array}{l}\text { Daun } \\
\text { sendok }\end{array}$ & $\begin{array}{l}\text { Plantagin, aukubin, } \\
\text { asam ursolik, betasi } \\
\text { torsterol, n- } \\
\text { hentriakontan, tannin, } \\
\text { kalium, vitamin (B1, } \\
\text { C, A) dan plantagliside }\end{array}$ & $\begin{array}{l}\text { Memperlancar kencing, } \\
\text { kencing berdarah, } \\
\text { disentri, diare, mimisan } \\
\text { dan batuk darah }\end{array}$ & Herbie, 2015 \\
\hline 15. & Katu & $\begin{array}{l}\text { Vitamin } \mathrm{K} \text {, pro vitamin } \\
\text { A, B dan C, mineral } \\
\text { kalsium, kalium, fosfor } \\
\text { dan magnesium }\end{array}$ & $\begin{array}{l}\text { Memperlancar } \\
\text { pengeluaran ASI, } \\
\text { mengatasi sembelit, } \\
\text { mengobati luka }\end{array}$ & $\begin{array}{l}\text { Santoso, } \\
2008\end{array}$ \\
\hline 16. & Sereh & $\begin{array}{l}\text { Sitral, sitronelol (66- } \\
85 \% \text { ), kamfen, sabinen, } \\
\text { limonen, terpinol, } \\
\text { sitronelal, borneol, } \\
\text { geraniol, farnesol, } \\
\text { metil heptenon, } \\
\text { ndesialdehida, } \\
\text { dipenten, bornilasetat, } \\
\text { geranilformat, terpinil } \\
\text { asetat, sitronelil asetat, } \\
\text { geranil asetat }\end{array}$ & $\begin{array}{l}\text { Penambah nafsu makan, } \\
\text { pengobatan pasca } \\
\text { persalinan, penurun } \\
\text { panas serta pereda } \\
\text { kejang }\end{array}$ & Herbie, 2015 \\
\hline 17. & Sambiloto & $\begin{array}{l}\text { Asam kersik, alkane, } \\
\text { keton, aldehid }\end{array}$ & $\begin{array}{l}\text { hepatitis, infeksi saluran } \\
\text { empedu, disentri } \\
\text { basiler, tifoid, diare, } \\
\text { influenza, amandel, } \\
\text { radang paru-paru, } \\
\text { radang saluran napas, } \\
\text { demam, diare, kencing } \\
\text { nanah, kencing manis } \\
\text { dan lain-lain }\end{array}$ & Herbie, 2015 \\
\hline 18. & Murbei & $\begin{array}{l}\text { Ecdysterone, } \\
\text { inokosterone, lupeol, } \\
\text { betasitosterol, } \\
\text { moracetin, trigonelline, } \\
\text { cholin, adenine, asam } \\
\text { folat, zinc, vitamin (A, } \\
\text { B1, D) dan karoten }\end{array}$ & $\begin{array}{l}\text { Hipertensi, kaki } \\
\text { bengkak, kencing } \\
\text { nanah, bisul, rematik, } \\
\text { hepatitis, dan anemia }\end{array}$ & Herbie, 2015 \\
\hline 19. & Jahe gajah & $\begin{array}{l}\text { Zat enzim protease, } \\
\text { enzim lipase dan }\end{array}$ & $\begin{array}{l}\text { Mengobati asam urat } \\
\text { dan antiradang }\end{array}$ & Herbie, 2015 \\
\hline
\end{tabular}




\begin{tabular}{|c|c|c|c|c|}
\hline & & hormone adrenalin & & \\
\hline 20. & Jahe merah & $\begin{array}{l}\text { Oleoresin, zat gingerol, } \\
\text { oleoresin, dan minyak } \\
\text { atsiri yang lebih tinggi } \\
\text { dari klon jahe lainnya }\end{array}$ & $\begin{array}{l}\text { mengobati pencernaan, } \\
\text { perut kembung, sakit } \\
\text { kepala, sakit } \\
\text { kerongkongan, mulas } \\
\text { dan batuk kering }\end{array}$ & $\begin{array}{l}\text { Rukmana, } \\
2001\end{array}$ \\
\hline 21. & Kunyit & $\begin{array}{l}\text { Kurkuminoid, minyak } \\
\text { atsiri, fosfor, protein, } \\
\text { zat besi, kalium, } \\
\text { vitamin C, } \\
\text { astringensia, flavonoid, } \\
\text { sulfur, alkaloid, dan } \\
\text { saponin }\end{array}$ & $\begin{array}{l}\text { Mengobati berbagai } \\
\text { jenis penyakit seperti } \\
\text { hipertensi, liver, } \\
\text { antiinflamasi, anti } \\
\text { bakteri, antiplasmodik } \\
\text { dan menambah nafsu } \\
\text { makan }\end{array}$ & Rusita, 2017 \\
\hline 22. & Temulawak & $\begin{array}{l}\text { Flavonoid, fenol, } \\
\text { fellandrean, minyak } \\
\text { atsiri, kamfer, } \\
\text { glukosida, dan } \\
\text { kurkumin }\end{array}$ & $\begin{array}{l}\text { Mencegah terjadinya } \\
\text { kerusakan sel, anti } \\
\text { sembelit, antiinflamasi, } \\
\text { antikanker, antidiabetes, } \\
\text { dan antimikroba }\end{array}$ & Rusita, 2017 \\
\hline 23. & Kencur & $\begin{array}{l}\text { Pati }(4,14 \%) \text {, mineral } \\
(13,73 \%), \text { minyak } \\
\text { atsiri }(0,02 \%) \text {, saponin, } \\
\text { flavonoid dan senyawa } \\
\text { polifenol }\end{array}$ & $\begin{array}{l}\text { obat sakit perut, } \\
\text { penambah nafsu makan, } \\
\text { menghangatkan badan, } \\
\text { pelangsing, dan sakit } \\
\text { perut. Minuman kencur } \\
\text { dapat mengobati radang } \\
\text { lambung, batuk, } \\
\text { perlancar haid, dan } \\
\text { badan lelah }\end{array}$ & Herbie, 2015 \\
\hline 24. & Mengkudu & xeronin dan scopoletin & $\begin{array}{l}\text { Menurunkan tekanan } \\
\text { darah tinggi karena } \\
\text { mengandung scopolatin } \\
\text { yang dapat melebarkan } \\
\text { pembuluh darah yang } \\
\text { menyempit, sehingga } \\
\text { menjadikan mengkudu } \\
\text { dapat mengontrol } \\
\text { tekanan darah, menjaga } \\
\text { stabilitas darah normal } \\
\text { penderita diabetes } \\
\text { dalam jangka panjang }\end{array}$ & Rusita, 2017 \\
\hline & Delima & $\begin{array}{l}\text { Alkaloid, tannin, } \\
\text { kalsium, oksalat, } \\
\text { lemak, sulfur dan } \\
\text { peroksidase }\end{array}$ & $\begin{array}{l}\text { Menurunkan berat } \\
\text { badan, cacingan, } \\
\text { sariawan, hipertensi, } \\
\text { rematik dan perut } \\
\text { kembung }\end{array}$ & Herbie, 2015 \\
\hline 26. & Kayu manis & Flavanoid, saponin, & Menghambat & Rusita, 2017 \\
\hline
\end{tabular}




\begin{tabular}{|c|c|c|c|}
\hline & dan alkanoid & $\begin{array}{l}\text { pembentukan radikal } \\
\text { bebas yang berbahaya } \\
\text { dan membantu } \\
\text { memperlambat } \\
\text { komplikasi diabetes }\end{array}$ & \\
\hline 27. Som jawa & - & $\begin{array}{l}\text { Mengatasi kondisi } \\
\text { badan lemah, banyak } \\
\text { berkeringat, pusing, } \\
\text { batuk, tuberculosis } \\
\text { paru-paru, nyeri } \\
\text { lambung, diare dan } \\
\text { keputihan }\end{array}$ & $\begin{array}{l}\text { Dalimartha, } \\
2000\end{array}$ \\
\hline 28. Kopi & $\begin{array}{l}\text { Koffeol, kofein (1- } \\
2 \%), 10-13 \% \text { minyak } \\
\text { lemak, } 2-5 \% \text { tannin, } \\
\text { protein glukosa, } \\
\text { dekstrin dan lain-lain }\end{array}$ & $\begin{array}{l}\text { Stimulans dan penawar } \\
\text { racun }\end{array}$ & $\begin{array}{l}\text { Tjietrosoepo } \\
\text { mo, } 2016\end{array}$ \\
\hline
\end{tabular}

\section{KESIMPULAN DAN SARAN}

Berdasarkan hasil penelitian dapat disimpulkan bahwa terdapat 27 jenis tumbuhan herbal dari kelas Dicotyledoneae dan Monocotyledoneae, terdiri atas 17 ordo, 19 famili dan 25 genus. Organ tumbuhan yang dimanfaatkan sebagai bahan baku minuman herbal fungsional adalah daun, rimpang, akar, buah, kulit kayu dan bijinya. Daun merupakan organ tumbuhan yang banyak dimanfaatkan.

\section{DAFTAR RUJUKAN}

Anwar, T. M., \& Soleha, T. U. (2016).Manfaat Daun Binahong (Anredera cordifolia) sebagai terapi Acne Vulgaris.Majority, (Online), Vol. 5, No. 5, http://juke.kedokteran.unila.ac.id/index.php/majority/article/view/906/814, diakses 6 Juni 2018).

Dalimartha, S. (2000).Atlas Tumbuhan Obat Indonesia.Bogor : Trobus Agriwidya.

Hakim, L. (2015).Rempah dan Herba. Malang: Diandra Creative.

Herbie, T. (2015). Kitab Tanaman Berkhasiat Obat. Yogyakarta: Octopus Publishing House.

Kartika, I. (2017). Potensi Herbal sebagai Minuman Fungsional. Pangan Fungsional, (Online), (https://pangan-fungsional.tp.ugm.ac.id/artikel/2017/55-potensiherbal-sebagai-minuman-fungsional.html, diakses 12 Maret 2018) 
Lentera. (2002). Khasiat dan Manfaat Jahe Merah si Rimpang Ajaib. Jakarta: Agromedia Pustaka.

Mabel, Y., Herny, S., \& Koneri, R. (2016). Identifikasi Dan Pemanfaatan Tumbuhan Obat Suku Dani Di Kabupaten Jayawijaya Papua. Jurnal MIPA UNSRAT, (Online), 5(2),(https://media.neliti.com/.../115408-ID-identifikasi-danpemanfaatan-tumbuhan-ob.pdf, diakses 23 Januari 2018).

Mais, M., Simbala, H., \& Koneri, R. (2018).Pemanfaatan Tumbuhan Obat Oleh Etnis Sahu dan Loloda Di Halmahera Barat, Maluku Utara.Jurnal Mipa Unsrat, (Online), 7(1), (https://ejournal.unsrat.ac.id/index.php/jmuo/article/download/18811/18362, diakses 7 Juni 2018).

Mulyani, H., Widyastuti, S. H., \& Ekowati, V. I. (2016).Tumbuhan Herbal sebagai Jamu Pengobatan Tradisional terhadap Penyakit dalam Serat Primbon Jampi Jawi Jilid I. Jurnal Penelitian Humaniora, (Online), 21(2), (https://journal.uny.ac.id/index.php/humaniora/article/view/13109, diakses 24 Januari 2018).

Nurrani, L. (2015). Kearifan Lokal dalam Pemanfaatan Tumbuhan Obat oleh Masyarakat di Sekitar Taman Nasional Aketajawe Lolobata, Provinsi Maluku Utara.Balai Penelitian Kehutanan Manado, (Online), 12(3), (http://ejournal.forda-mof.org/latihan/index.php/JPSE/article/view/965/909, diakses 23 Januari 2018).

Rifkowaty, E. E., \& Martanto.(2016). Minuman Fungsional Serbuk Instan Jahe (Zingiber officinale rosc) dengan Variasi Penambahan Ekstrak Bawang Mekah (Eleutherine americana merr) Sebagai Pewarna Alami. Jurnal Teknik Pertanian Lampung, (Online), 4(4), (https://media.neliti.com/media/publications/134382ID-none.pdf, diakses 24 Januari 2018).

Rusita, Y. D. (2017). Terapi herbal buah dan sayuran untuk 10 penyakit berbahaya. Surakarta: Galmas Publisher.

Santoso, H. B. (2008). Ragam dan Khasiat Tanaman Obat. Jakarta: Agromedia Pustaka Cetakan I.

Safratilof.(2016). Uji Daya Hambat Ekstrak Daun Kayu Manis (Cinnamomum burmanii) Terhadap Bakteri Aeromonas hydrophila.Jurnal Ilmiah Universitas Batanghari Jambi, (Online), 16(1), (https://media.neliti.com/media/publications/225462-uji-daya-hambat-ekstrakdaun-kayu-manis-d2dd1bdb.pdf, diakses 7 Juni 2018). 
Soetarno, S., Suganda, A. G., Sugihartina, G., \& Sukrasno, S. (2000). Flavonoid dan asam-asam fenolat dari daun dewa [Gynura procumbens (Lour.)Merr]. Warta Tumbuhan Obat Indonesia., (Online), Vol. 6, (http://ejournal.litbang.depkes.go.id/index.php/wtoi/article/view/1363, diakses 6 Juni 2018)

Sugiyono.(2015). Metode Penelitian Pendidikan. Bandung: Alfabeta.

Sutanto.(2010). Cekal Penyakit Modern Hipertensi, Stroke, Jantung, Kolesterol, dan Diabetes. Yogyakarta: C.V Andi Offset.

Sutjiatmo, A. B., Sukandar, E. Y., Candra, \& Vikasari, S. N. (2015). Uji Toksisitas Akut Ekstrak Air Herba Pecut Kuda (Stachytarpheta jamaicensis (L) Vahl) Pada Mencit Swiss Webster. Kartika-Jurnal Ilmiah Farmasi, (Online), 3(2), (kjif.unjani.ac.id/index.php/kjif/article/view/103, diakses 6 Juni 2018).

Tasia, W. R., \& Widyaningsih, T. D. (2014). Potensi Cincau Hitam (Mesona palustris Bl.) Daun Pandan (Pandanus amaryllifolius) Dan Kayu Manis (Cinnamomum burmannii) Sebagai Bahan Baku Minuman Herbal Fungsional. Jurnal Pangan dan Agroindustri, (Online), 2(4), (http://jpa.ub.ac.id/index.php/jpa/article/view/85, diakses 26 Januari 2018).

Tisnadjaja, D., Hidayat, S. L., Sumirja, S., \& Simanjuntak , P. (2006). Pengkajian Kandungan Fitosterol pada Tanaman Kedawung (Parkia roxburgii G. Don.). Biodiversitas, (Online), 7(1), (http://biodiversitas.mipa.uns.ac.id/D/D0701/D070107.pdf, diakses 6 Juni 2018).

Tjietrosoepomo, G. (2016). Taksonomi Tumbuhan Obat-obatan. Yogyakarta: Gadjah Mada University Press.

Yansip, S. M., Tambaru, E., \& Salam, M. A. (2017). Jenis-jenis tumbuhan berkhasiat obat tradisional di masyarakat desa Yanim dan Braso Distrik Kemtuk Gresik Kabupaten Jayapura. Jurnal Biologi Makasar, (Online), 2(2), (journal.unhas.ac.id/index.php/bioma/article/view/2027/0, diakses 23 Januari 2018). 